\title{
Tulajdonnevek a nyelvatlaszokban
}

1. A nyelvatlasz mint forrás. A nyelvatlaszok, jellegükből adódóan, alkalmasak az egy adott időpontban élő nyelvállapotot rögzíteni, s ez kiindulópontként szolgálhat a területi összefüggések azonosításához, vizsgálatához. A nyelvatlaszok létrejöttét, illetve a gyüjtéseket alapvetően nem névtani szempontok motiválták, de a gyüjtött nyelvi anyagok bizonyos keretek között alkalmasak lehetnek névtani tanulságok levonására is, továbbá forrásként szolgálhatnak összehasonlító vizsgálatokban.

1.1. Lehetőségek és korlátok. A nemrég megjelent Tulajdonnevek és szótárak címü átfogó szakkönyvben (FARKAS-SLíz szerk. 2020) JuHÁsz Dezső tanulmánya hívja fel a figyelmet a nyelvatlaszokban található tulajdonnevekre is (JuHÁsz 2020: 59-60). A tanulmányában vizsgált tájszótárakkal sok rokon vonást mutató nyelvatlaszok anyagának általános áttekintését mostanra megkönnyíti, hogy elkészült az 1959-2012 között megjelent 26 magyar nyelvatlasz címszóanyagának rendszerezése és egységes mutatója (SzABó 2018b: 215-445).

A nevek azonban „típusuktól függően eltérő mértékben adnak alapot területi megoszlás szerinti, nyelvföldrajzi következtetésekre. A keresztnevek például korábban éppen ebből a megfontolásból kevésbé keltették fel a nem névtanos kutatók érdeklődését", állapítja meg Vörös FERENC (2006: 171). A magyar névföldrajzi kutatások (áttekintését l. BÁRTH M. 2018: 23-30, SzABó 2018a) mind a személy-, mind a földrajzi nevek terén jelentős eredményeket értek el, a szinkrón és a diakrón vizsgálatokban egyaránt.

A nyelvatlaszok szóállományában szinkrón vizsgálatok esetén elsősorban az adott területre jellemző nyelvjárási sajátosságok, az esetleges alaki, grammatikai változatosság érhető tetten. A nyelvatlaszokban személy- és földrajzi nevek egyaránt szerepelnek, és alapvetően mindegyikre igaz ez a megállapítás. Azonban ha időbeli síkra helyezzük őket, jellegükből adódóan névtani, müvelödéstörténeti tanulságokat is hordozhatnak. Általánosságban a diakrón szempontú megközelítési lehetőséget a keresztnevek kutatásában HAJDú MıнÁLY a következőképpen foglalja össze: „A dialektológiát annyiban szolgálja az eddigi kutatás, hogy megmutatja azokat a hatásokat, amelyek érik az egyik népcsoportot a másiktól. Ezek iránya segít a nyelvjárási hatások földerítésében. A névtani változások ugyanis százszorta gyorsabbak akár a hangtani vagy grammatikai változásoknál, de az átadás-átvétel mechanizmusa hasonlóképp müködik. A nevek a lexikológia témakörébe is tartozó nyelvtani elemek, s a tájszavak terjedéséhez hasonló a változásuk. Amíg azonban a tájszavak megjelenése, továbbvándorlása nem mérhetö, nem jegyezték föl átadásuk pillanatában őket, a neveket a XVII. századtól már első jelentkezésükkor meg lehet találni a táj, város, falu kincsében, s nyomon lehet követni útjukat, vándorlásukat, különböző pontokon, egymástól való távoli helyeken való fölbukkanásukat." (HAJdú 2003: 409.) A nyelvatlaszok a 20. század második felének nyelvállapotát tárják fel (bizonyos esetekben „régies” minősítéssel korábbi alakokra is utalva), ezért az akár több évszázadot is felölelő diakrón szempontú vizsgálatokban 20. századi forrásként jelenhetnek meg. 
1.2. A nyelvatlaszok szókincséről. A papíralapon is megjelent 26 magyar nyelvatlaszban 13348 térképlap található, ami a címszóegyesítési munkálatok után 6090-re csökken. Ezek között mindössze 81 tulajdonnevet, elsősorban személy-, földrajzi és égitestneveket fedezhetünk fel. Ez rendkívül kevés: látványosan igazolódik, hogy a nyelvatlaszok készítésekor, a címszóállomány összeállításakor a névtani szempontok nem játszottak szerepet. Ugyanakkor ha tüzetesebben megnézzük a listát, azt látjuk, hogy a 26 magyar nyelvatlaszból csak öt zárja ki teljesen a neveket, mindössze ennyiben nem találunk tulajdonnévi térképcímszavakat: a három úgynevezett célatlaszunkban, a KKSzASz.-ben, a HVMA.-ban és az ÁllSA.-ban, továbbá a címszóállománya szempontjából is tekintélyes két dunántúli kiadványban, a ZsA.-ban és az SmA.-ban.

Mi lehet ennek az oka? A 21 névbefogadó nyelvatlaszban kiegyensúlyozottságot nem fedezhetünk fel. A tulajdonnevek negyede A romániai magyar nyelvjárások atlaszában (RMNyA.: 45 db , 24\%) jelenik meg, ezt követi A kárpátaljai magyar nyelvjárások atlasza (KárpA.: $29 \mathrm{db}, 16 \%$ ) és A moldvai csángó nyelvjárás atlasza (CsángA.: $23 \mathrm{db}, 12 \%$ ). Nemzeti atlaszunk, a csaknem az egész magyar nyelvterületet átfogó A magyar nyelvjárások atlasza (MNyA.) csak a negyedik helyre szorul (12 db, 7\%), ami azért is jelzésértékü, mert a később készült nyelvatlaszok általában igyekeztek igazodni az MNyA. szókincséhez, s átvenni belőle a saját kutatási területükön valamilyen szempontból fontos címszavakat. A többi atlaszban tíz alatt marad a tulajdonnevek száma.

A nagyatlasz és a táji nyelvatlaszok egymáshoz való viszonyát és feladatkörét elsőként VÉGH JózSEF foglalta írásba az Örségi és hetési nyelvatlasz bevezetőjében (ŐHA. 11-22). Korábbi francia mintát követve az ajánlás szerint a nemzeti atlaszok igyekezzenek országhatárok nélkül a nyelv minden nyelvjáráscsoportját átfogni, nagy vonalakban bepillantást engedve a nyelvi változásokba. De emellett ,a Magyar Nyelvatlaszon kívül szükség van a kisebb, egy-egy vidékre szorítkozó, de egészen sürü hálózatú nyelvjárási térképekre, melyek esetleg kevesebb számú jelenséggel, kevesebb fogalomkör szókincsével foglalkoznak, de a szavak és jelenségek megoszlását apróbb részleteikben elénk tárva tanulságosan világítják meg a nyelvi elemek küzdelmeit" (ÖHA. 11). Az ebben a szellemben készült regionális atlaszok egy-egy szükebb területet, földrajzi, néprajzi vagy nyelvjárási egységet és esetleg a környékét tárják fel teljes sürüségü kutatópont-hálózaton, az adott vidékre jellemző nyelvjárási jelenségekre is fókuszálva.

A gyüjtendő anyag kijelölésekor ,az atlasznak számot kell adnia nemcsak egy bizonyos számú fogalom nyelvbeli kifejezéseinek megoszlásáról, hanem a fontosabb nyelvjárási hangtani és alaktani tények földrajzi elterjedéséről [is]" - írta BÁrCZI GÉzA (1944: 19). A regionális atlaszok úttörőjének tekinthető ÖHA.-ban is csak olyan tulajdonneveket találunk, amelyeket hangtani, alaktani céllal (100. Sándorékhoz, 101. Galambosékhoz, 105. Ferihez, 106. Ferinél) vettek fel. A magyar nyelvjárások atlasza kérdőfüzetének összeállítása kapcsán Deme LÁszló (1955: 51) tömören így fogalmaz: „A hangtan terén követelt lehetö teljességgel szemben az alaktan területén már csak a fontosabb jelenségek teljességét írja elö; a szókincsre vonatkozólag pedig eleve elhárítja a teljességre törekvésnek még a gondolatát is". A tulajdonnevek gyüjtéséről vagy szerepükröl a nyelvatlaszokban itt sem esik külön szó. Mindezekkel összhangban nem meglepö, hogy a tulajdonnevek a nyelvatlaszok teljes címszóállományának csak csekély százalékát adják. 
1. táblázat: Tulajdonnevek a nyelvatlaszok címszóállományában

\begin{tabular}{|l|r|l|r|l|r|}
\hline \multicolumn{1}{|c|}{ Atlasz } & \multicolumn{1}{c|}{$\mathbf{\%}$} & \multicolumn{1}{c|}{ Atlasz } & \multicolumn{1}{c|}{$\mathbf{\%}$} & \multicolumn{1}{c|}{ Atlasz } & \multicolumn{1}{c|}{$\mathbf{~}$} \\
\hline MNyA. & 0,56 & MurA. & 1,16 & JSzA. & 1,83 \\
\hline RMNyA. & 0,74 & ÖHA. & 1,00 & SzerA. & 1,46 \\
\hline SzilA. & 0,44 & SZA. & 0,18 & BNyA. & 1,39 \\
\hline SzNySz. & 0,18 & OrmAM. & 0,72 & MedvA. & 0,29 \\
\hline CsángA. & 1,19 & JBarA. & 1,89 & NybA. & 0,69 \\
\hline HétfA. & 0,66 & SzlavA. & 1,03 & KárpA. & 1,13 \\
\hline NyvA. & 1,19 & JBánA. & 2,10 & HHNyA. & 2,70 \\
\hline
\end{tabular}

A tulajdonnevek száma alapján a határon túli atlaszkészítők nagyobb hangsúlyt fektettek a tulajdonnevek gyüjtésére, de önálló tematikus egységként csak a kárpátaljai atlaszban jelennek meg (KárpA. 1143-1171-es térképlapok) keresztnevek és becéző alakjaik. PenAvin Olga hét nyelvatlasza a leghomogénebb csoportot alkotja a magyar nyelvatlaszok között. Több szempontból is nagyarányú egyezést mutatnak, mert szinkrón időpontban, azonos gyüjtő személye által és azonos lejegyzési módszer szerint készültek. Nincs ez másként a tulajdonnevek gyüjtése terén sem: jellemzően ugyanazokkal a keresztnevekkel kérdez rá a hangtani és alaktani sajátosságokra. Az erdélyi nyelvatlaszok is közel azonos kérdőívvel, azonos felkészültségü gyüjtőkkel, az adatközlők azonos szempontú kiválasztásával dolgoztak, PenAvin Olga atlaszaihoz hasonlóan itt is jobb lehetőségeket teremtve az összehasonlító nyelvföldrajzi vizsgálatokra.

Az összesített kimutatást megnézve a nyelvatlaszok többségében elenyészőnek mondható a tulajdonnevek előfordulása. Azonban a címszavak egymáshoz igazodása, az azonos denotátumú kifejezések gyüjtése miatt már ezek az apró egyezések is több esetben lehetővé tehetnek több atlaszt - s ennek köszönhetően egymástól távolabb fekvő területeket - érintő vizsgálatokat.

2. Személynevek. Személynevek 20 nyelvatlaszban találhatók, a névbefogadó atlaszok közé sorolható munkák közül egyedül a Székely nyelvföldrajzi szótárban (SzNySz.) nem. A személynevek gyakoriságuk szerint csökkenő sorrendben a következők (a címszó mellett zárójelben az atlaszok rövidítését is közlöm).

Kimagaslóan sokban, tizenkét atlaszban szerepel a Ferenchez címszó (MNyA., RMNyA, MurA., JBarA., SzlavA., JBánA., JSzA., SzerA., BNyA., MedvA., NybA., HHNyA.), majd ezt hét elöfordulással a Sándorékhoz követi (MNyA., RMNyA., SzilA., HétfA., NyvA., ÖHA. és HHNyA.). A képzeletbeli dobogó harmadik fokán egy holtversenyt találunk, a Sándor két újabb ragozott alakját, a Sándoréknál (MNyA., RMNyA., SzilA. HétfA., NyvA. HHNyA.) és a Sándoréktól (MNyA., RMNyA., SzilA. HétfA., NyvA. HHNyA.) formát. Öt atlaszban az Erzsiékhez (MNyA., RMNyA., CsángA., MedvA., HHNyA.) és a Katalin 2 (fiatal) (JBarA., MurA., SzlavA., JSzA., BNyA.), négyben az Anna (becealakjai) (RMNyA., CsángA. JSzA., KárpA.), a József (becealakjai) (RMNyA., CsángA. JSzA., KárpA.), a Katalin 1 (JBarA., SzlavA., SzerA. KárpA.) és a Mihály (MNyA., RMNyA., NyvA. KárpA.) neveket találjuk. 
A három atlaszban fellelhető címszavaknál magas a RMNyA., a CsángA. és a KárpA. egyezése, az e három atlaszban található címszavak: György (becealakjai), János (becealakjai), Mária (becealakjai). Az RMNyA. és a CsángA. mellett a HHNyA.-ban szerepel az Erzsiéknél, az MNyA., RMNyA. és JSzA. hármasban a Ferencnél, míg az MNyA.-ban, az RMNyA.-ban és a KárpA.-ban a Károly. Három PeNAvin-atlaszban a Katalin néni (megszólítás) (JSzA., SzerA., BNyA.) fordul elö.

A 66 személynév közel 80\%-a, azaz 48 név csupán egyszer vagy kétszer fordul elő a nyelvatlaszokban, ezzel is mutatva, hogy összességében nem beszélhetünk tudatos egyezésre törekvésröl. Két romániai nyelvatlasz, az RMNyA. és a CsángA. több ponton is kapcsolódik egymáshoz: közösek az Erzsiéktöl, Erzsihez, Erzsinél, Erzsitöl, Józsiékhoz, Józsiéknál, Józsiéktól, Józsihoz, Józsinál és Józsitól ragozott címszavak. Szintén az RMNyA. az egyik lelőhelye a Kati, Mihályé és Mihálytól alakoknak, de már változatos másik forrással; míg a maradék öt kétszer előforduló címszó - Ferihez, István, Katalin 3 (idős), okosabb Pistánál, Pistáék földje - egyezése az atlaszokban véletlenszerüséget sugall.

A személynevek több mint fele csak egyetlen atlaszban fordul elö. Ezek közül kiemelkedik a KárpA., melyben egy külön blokkba rendezve találjuk őket, innen származik az András, Béla, Erzsébet, Ferenc, Gizella, Gyula, Irén, Jolán, Júlia, Lajos, László, Magdolna, Margit, Miklós, Pál, Péter, Sándor, Zoltán és a Zsuzsanna. Viszonylag sok nevet az RMNyA. kínál még, melyben az Erzsi, Erzsiék, Erzsiéké, Józsiék, Józsiéké, Pista, Pistánál (fiatalabb) grammatikai szempontú térképlapokat vizsgálhatjuk. Az ÖHA.-ban a Ferinél és a Galambosékhoz, az SZA.-ban a Terinél, az OrmAM.-ban az Aurél, a JSzA.ban a Ferenctöl, míg a HHNyA.-ban egy összetettebb térképlap, az Erzsiékhez/Erzsiéknél típusváltozó található.

Összességében a legtöbb személynevet az RMNyA.-ban találjuk, s ezek közül többnek - az alapalakban lévő Károly (1412) és Mihály (1429) címszavak, továbbá a toldalékos alakok közül az -é birtokjeles Mihályé (1430) - elemzését JuHÁsz Dezsö végezte el (JuHÁsz 1999). A -nott, -nól, -ni családi helyhatározóragok variánsai az Erzsitöl, Erzsihez, Erzsinél, Erzsiéktöl, Erzsiékhez, Erzsiéknél; Ferencnél, Ferenchez; Józsitól, Józsihoz, Józsinál, Józsiéktól, Józsiékhoz, Józsiéknál; Sándoréknál, Sándoréktól, Sándorékhoz térképlapokon vizsgálhatók. Ezekből Murádin LÁszló (1966) és Hegedüs Andrea (2008: 93-104) készített esettanulmányt, illetve átfogó elemzést. Az erdélyi atlaszokban több címszó esetében is feltünő az ismétlődés, így ezek - a gyüjtés ideje, módszere miatt is - kiemelten alkalmasak átfogóbb vizsgálatokra.

A személynevek között tekintélyes tábort képvisel a becenevek csoportja: a nyelvatlaszokban találunk Erzsi, Gyuri, Jani, Józsi, Kati, Mari és Pista címszavú térképlapokat is. Újabb vizsgálati lehetőségeket tartogat, hogy a Kati becenevet az idősebb és a fiatalabb korosztályra vonatkoztatva egyaránt kikérdezték, külön-külön térképlapokat készítve róla. Ez sajnálatos módon azonban egyedi eset, pedig az efféle gyüjtés és életkorhoz kötődő összehasonlítás a változások tágabb horizontját nyithatnák meg a nyelvatlaszok névtani szempontú felhasználásának.

A nyelvatlaszok összevethetősége, valamint a többes egyezés miatt elsőként a Katalin 2 (fiatal)-t választottam ki bemutatásra. 


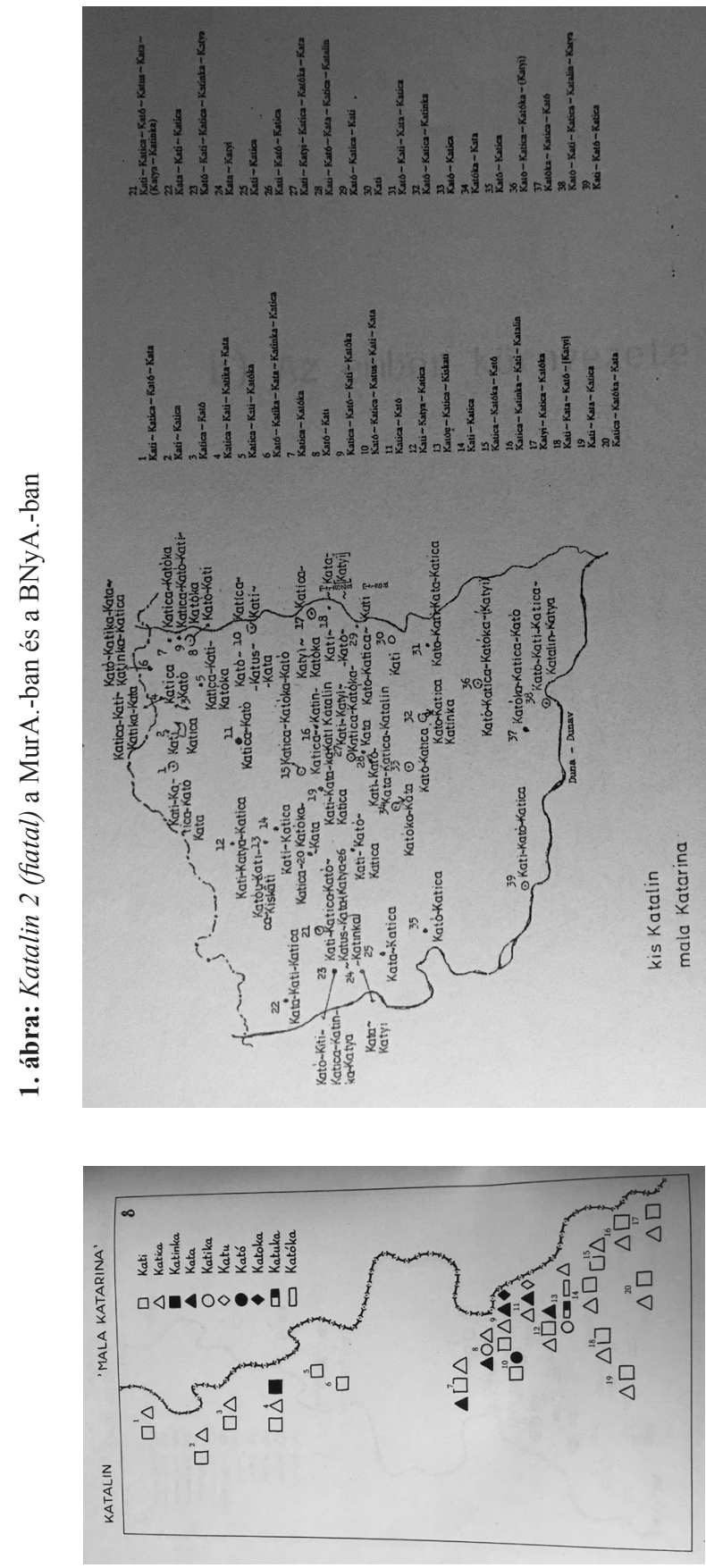


2. táblázat: Katalin 2 (fiatal) a nyelvatlaszokban ${ }^{1}$

\begin{tabular}{|l|r|r|r|r|r|}
\hline & JBarA. & MurA. & SzlavA. & JSzA. & BNyA. \\
\hline Kata & 2 & 5 & 3 & & 14 \\
\hline Katalin & & & & & 3 \\
\hline Kati & 4 & 17 & 9 & & 22 \\
\hline Katica & 10 & 17 & 10 & 3 & 34 \\
\hline Katika & 1 & 2 & & 3 & 2 \\
\hline Katinka & & 1 & 1 & & 4 \\
\hline Kató & 6 & 1 & 5 & & 20 \\
\hline Katóka & 1 & 2 & & & 10 \\
\hline Katu & & 1 & & & \\
\hline Katuka & & 1 & & & 2 \\
\hline Katus & & & 2 & & 4 \\
\hline Katya & & & & & 4 \\
\hline Katyi & & & & & \\
\hline Kiskati & & & & & \\
\hline
\end{tabular}

A Katalin 2 (fiatal) a JBarA. 8-as, a MurA. 8-as, a SzlavA. 9-es, a JSzA. 69-es és a BNyA. 20-as PENAVIN-atlasz térképlapja. A kutatópontokon elöforduló variánsok számbavétele és a hangtani kiegyenlítések után a következő megállapítások tehetők: 1. Az atlaszok kutatópontjainak eltérő számától függetlenül mind az öt atlaszban a Katica becenév végzett az első, többségében a Kati a második helyen, de ezeken kívül a Kató és a Kata is széles körben elterjedtnek, a gyüjtés időpontjában általánosan ismertnek és használtnak tekinthetők. 2. A hangtani kiegyenlítések után 14 becenevet találhatunk az atlaszokban. 3 . Az esetek többségében a csonkulással, illetve a képzővel ellátott becenévpárok mindkét tagja fellelhető. 4. A bácskai kutatópontokon mind a fellelhető becéző alakok mennyisége, mind a változatossága magasan meghaladja a többi területét (és mivel ez is PeNAvin-atlasz, feltételezhetjük, hogy hasonló eljárásmóddal készült). 5. A jugoszláviai székelytelepeken a Katica és a Katika alak is mindegyik kutatóponton jelen van.

A Katalin 2 (fiatal)-tól eltérően a Katalin 3 (idős) címszó csak két atlaszban található meg, a JBarA.-ban (7. térképlap) és a MurA.-ban (9. térképlap). A JSzA., a SzerA. és a BNyA. a Katalin néni (megszólitás) összetételt vizsgálja, ahol a térképlapokon a néni hangtani változásainak feltüntetésére kerül a hangsúly.

${ }^{1}$ A számok a névváltozatoknak a térképlapokon való előfordulásait jelzik. 
3. táblázat: Katalin 3 (idős) a nyelvatlaszokban

\begin{tabular}{|l|r|r|}
\hline & JBarA. & MurA. \\
\hline Kata & 3 & 15 \\
\hline Katalin & & 1 \\
\hline Kati & 7 & 14 \\
\hline Katica & 5 & 1 \\
\hline Kató & 4 & \\
\hline
\end{tabular}

Ha összevetjük a két címszóállományt, láthatjuk, hogyan változik az idő előrehaladtával az egyes becealakok használata. Az egységes területi lefedettség érdekében a mindkét változatot kezelö két atlasz, a JBarA. és a MurA. adatai alapján a következők állapíthatók meg: 1. A Kata és a Kati becealakok használata a kor előrehaladtával erősödik. 2. A Katica és a Kató ellenben arányaiban csökken. 3. Ezen atlaszok szerint a Katalint-t csak az idősek megnevezésére használják, a fiatalokra egyáltalán nem. 4. A fiatal Katalinok becealakjai sokkal nagyobb variabilitást mutatnak $(9: 5)$, és idősebb korban már nem használják a $K a$ tika, Katinka, Katóka, Katu és Katuka, jellemzően kicsinyítőképzős alakokat.

3. Hely- és égitestnevek. A 26 magyar nyelvatlaszban a személyneveken kívül találhatunk még helyneveket és égitestek neveit is. Elöfordulásuk szerint csökkenő sorrendben: 9 atlaszban a Tejút (MNyA., RMNyA., SzilA., SzNySz., CsángA., HétfA., JBánA., MedvA., KárpA.); 7 atlaszban a Fiastyúk (RMNyA., SzilA., SzNySz., CsángA., HétfA., JBánA., JSzA.) és a Göncölszekér (MNyA., RMNyA., SzilA., SzNySz., HétfA., JBánA., MedvA.); 3 atlaszban a Hold (RMNyA., CsángA., JBánA.); 2 atlaszban az Esthajnalcsillag (RMNyA., CsángA.) és 1-1 atlaszban a Hajnalcsillag (CsángA.), Kaszás (Orion) (JBánA.), Kolozsváron (RMNyA.), Kolozsvárra (RMNyA.), Maros (RMNyA.), Marosvásárhelyen (RMNyA.), Marosvásárhelyre (RMNyA.), Nagy Göncöl (CsángA.), Sarkcsillag (JBánA.) és Szamos (RMNyA.).

Ilyen tulajdonneveket mindössze 10 nyelvatlaszban találunk, de a személyneveknél sokkal kisebb számban. Közülük kiemelkednek a romániai atlaszok, ezekhez ugyanis viszonylag következetesen kikérdezték ugyanazokat a címszavakat. A többinél az egyezés esetlegesnek tünik, egyedül az égitestnevek miatt kapcsolódik a JBánA. több ponton is az erdélyi atlaszokhoz.

Az RMNyA. névkészletét vizsgáló tanulmányban JuHÁsz Dezső elvégezte a két folyónév, a Maros és a Szamos nyelvföldrajzi elemzését (JuHÁsz 1999: 396-397), továbbá a toldalékos helynevekét, a Kolozsváron, Kolozsvárra, Marosvásárhelyen, Marosvásárhelyre címszavú térképlapokét is (JuHÁsz 1999: 397).

Nyelvészeti vizsgálatokra különösen kívánkoznak az égitestnevek, melyeknél a hangtani különbségeken túl az egyes morfematikai és lexikai változatok is azonosíthatók, majd népi, kulturális motivációjuk kutatható.

4. További vizsgálati lehetőségek. Ha a nyelvatlaszokban található tulajdonnévi címszavakat, az egyezéseiket, összevethetőségüket, illetve az eddig készült elemzéseket nézzük, megerösítést nyer, hogy névtani szempontú használatuk meglehetősen korlátos. 
A gyüjtők elsősorban eszközként használták őket a grammatikai jelenségek, leginkább a toldalékok táji változatainak bemutatásához - a nyelvatlaszok eredendő céljaival összhangban.

4.1. Tulajdonnevek alapjául szolgáló közszók. Ha eggyel visszább lépünk a tulajdonnevektöl, a nevek alapjául szolgáló közszókra is értékes információhordozóként tekinthetünk.

A nyelvatlaszok névtani vonatkozású felhasználásának sokkal tágabb horizontját nyitja meg, ha a földrajzi közneveket és a személynévi közszókat (foglalkozásneveket, külső és belső tulajdonságra utaló mellékneveket) is számba vesszük. Külön vizsgálati lehetőségként tarthatjuk számon azokat a közneveket, amelyek valamely személy- vagy földrajzi név részei vagy azok alapjául szolgálnak, és e kifejezések száma a nyelvatlaszokban jelentősen meghaladja a tulajdonnevekét. A teljesség igénye nélkül többek között a következő címszavakat találhatjuk meg: alsó 1 ('alul lévő'), árva, asztalos, bába, bátor, bíró, bokor, borbély, csordás, csorgó, csősz, domb, falu, farkas, fazekas, fej 2 (testrész), folyó, forrás, föld, hegy, juhász, kanász, karácsony, kerekes, kert, két, kovács, kövér, kút, külsö, mezö, patak, rét, sarok, sebes (folyóvíz), serény, szücs, tó, völgy (bővebben 1. JuHÁsz 1999: 399-400, szóföldrajzi vizsgálatokra pl. KÁzMÉR 1970, VöRÖs O. 1999). A lista még nagyon hosszan lenne folytatható, és általánosan megállapítható, hogy a három úgynevezett célatlasz (KKSzASz., HVMA. és az ÁllSA.) kivételével mindegyik kiadványban szép számmal fordulnak elö, igen magas egyezési arányokat mutatva.

A közszavak jelentőségét a közszói eredetü családnevek felöl is megközelíthetjük. Ezek önmagukban hordozzák a közösség egykori nyelvjárásának sajátosságait, és ezért alkalmasak lehetnek nyelvjárástörténeti vizsgálatokra is (N. Fodor 2016: 19). Az ilyen jellegü kutatásokhoz több és különböző időszakokból származó forrás használata szükséges (1. pl. FARKAS 2014; N. FodOr 2014, 2016; BÁRTH M. 2016), ami már átvezet minket a források integrálásának kérdéséhez.

4.2. Integrálás. A nyelvatlaszok kiválóan müködhetnek különböző összehasonlító elemzésekben. Az eltérö típusú korpuszok integrálásából remélhető eredmények mind szinkrón, mind diakrón szempontból messze túlmutatnak a saját típusú forrásanyagok összehasonlító elemzésein. A nyelvatlaszok tulajdonnévanyaga legkézenfekvőbb módon a tájszótárakéval lenne egybevethetö, s bennük a keresztnevek becealakjai különösen sok összevetési lehetőséget kínálnak (1. JuHÁsz 2020: 60). Az efféle egyesítésekbe, adatbázis-építésekbe a hely- és személynévtárak is az elsők között lennének bevonhatók (JuHÁsz 2001: 120). Tágabb időtávlatban pedig a nyelvatlaszok anyaga is része lehetne egy egyesített dialektológiai adatbázisnak.

\section{Felhasznált források}

ÁllSA. = BALOGH LAJOS - KIRÁLy LAJos, Az állathangutánzó igék, hívogatók és terelők somogyi nyelvatlasza. Akadémiai Kiadó, Budapest, 1976.

BNyA. = Penavin Olga, Bácskai magyar nyelvjárási atlasz. A Magyar Nyelv, Irodalom és Hungarológiai Kutatások Intézete, Újvidék, 1988.

CsángA. = A moldvai csángó nyelvjárás atlasza 1-2. Szerk. Gálffy Mózes - Márton Gyula - Szabó T. Attila. A Magyar Nyelvtudományi Társaság Kiadványai 193. Magyar Nyelvtudományi 
Társaság, Budapest, 1991. A III. kötet térképlapjai. [elektr. dok.] http://geolingua.elte.hu/projects/ mcsnya3 cimszok.pdf (2017. augusztus 19.)

HétfA. = VöÖ István, Hétfalu nyelvjárási atlasza. Babeş-Bolyai Tudományegyetem, Kolozsvár, 1971.

HHNyA. = Változó nyelvhasználat a hármas határ mentén: többdimenziós nyelvföldrajzi térképlapok tanúságai. Szerk. P. LaKaTos IlonA. Tinta Könyvkiadó, Budapest, 2012.

HVMA. = GUTTMANN MiKLós - KöBÖLKUTI Katalin, Hangutánzó igék vasi és muravidéki atlasza . A Magyar Nyelvtudományi Társaság Kiadványai 182. Magyar Nyelvtudományi Társaság, Budapest, 1987.

JBánA. = Penavin Olga, A jugoszláviai Bánát magyar nyelvjárási atlasza. CNESA Kiadó, Oktatási és Müvelődési Intézmény, Cnesa [Kanizsa], 1995.

JBarA. = Penavin Olga, A jugoszláviai Baranya magyar tájnyelvi atlasza. Újvidéki Egyetem, Újvidék, 1969.

JSzA. = Penavin Olga - Matijevics Lajos, A jugoszláviai székelytelepek nyelvatlasza . Magyar Nyelv, Irodalom és Hungarológiai Kutatások Intézete, Újvidék, 1978.

KárpA. = LizAnec, P[ETRo] N[IKOLAeviČ], A kárpátaljai magyar nyelvjárások atlasza 1-3. Szerk. Balogh Lajos etc. Akadémiai Kiadó etc., Budapest etc., 1992-2003.

KKSzASz. $=$ TıMAFFY LÁszLÓ, A kisalföldi kocsik és szekerek szakszókincsének nyelvatlasza és szótára. Magyar Csoportnyelvi Dolgozatok 22. ELTE Magyar Nyelvtörténeti és Nyelvjárási Tanszék - MTA Nyelvtudományi Intézet, Budapest, 1985.

MedvA. $=$ Cs. Nagy LaJos, Medvesalja magyar nyelvjárási atlasza. Luminosus n. o. Kiadó, Nagykapos, 2011.

MNyA. = A magyar nyelvjárások atlasza 1-6. Szerk. Deme LÁszló - Imre SAmu. Akadémiai Kiadó, Budapest, 1968-1977.

MurA. = Penavin Olga, A jugoszláviai Muravidék magyar tájnyelvi atlasza. A Magyar Nyelvtudományi Társaság Kiadványai 116. Magyar Nyelvtudományi Társaság, Budapest, 1966.

NybA. = Silling István, Nyugat-bácskai magyar nyelvatlasz. Forum Könyvkiadó - Újvidéki Egyetem Magyar Tannyelvü Tanítóképző Kar, Újvidék-Szabadka, 2012.

NyvA. $=$ SÁnDOR ANNA, A Nyitra-vidéki magyar nyelvjárások atlasza. Mercurius Könyvek. Kalligram, Pozsony, 2004.

OrmAM. = 1. Temesi MinÁly, Mutatvány az Ormánság nyelvatlaszából. A Pécsi Tanárképzö Föiskola Tudományos Közleményei 1965: 141-171. 2. Temesi MiнÁLy, Az Ormánság nyelvjárása 1939 és 1949 között. Szerk. Pesti János - Szücs Tibor. Dialóg Campus Kiadó, Pécs, 2002.

ÖHA. = VÉGH József, Örségi és hetési nyelvatlasz. Akadémiai Kiadó, Budapest, 1959.

RMNyA. = A romániai magyar nyelvjárások atlasza $1-11$. Gyüjt. és a kéziratot összeáll. MuRÁDIN LÁszló. Szerk. JuHÁsz Dezső. Magyar Nyelvtudományi Társaság / Magyar Nyelvtudományi Társaság - Pharma Press Kiadó, Budapest, 1995-2010.

SmA. = SaJtos JózSef, Sárviz menti nyelvatlasz. A Magyar Nyelvtudományi Társaság Kiadványai 220. Magyar Nyelvtudományi Társaság, Budapest, 2004.

SZA. = KIRÁLY LAJos, Somogy-zalai nyelvatlasz. Magyar Nyelvtudományi Társaság Kiadványai 223. Magyar Nyelvtudományi Társaság, Budapest, 2005.

SzerA. = Penavin Olga, A szerémségi magyar szigetek nyelve. Akadémiai Kiadó, Budapest, 1972.

SzilA. = Szilágysági nyelvatlasz. Gyüjt. MÁrton GyulA. Összeáll. és szerk. Hegedüs AtTILA. A Pázmány Péter Katolikus Egyetem Magyar Nyelvészeti Tanszékének Kiadványai 3. PPKE Magyar Nyelvészeti Tanszék, Piliscsaba, 2000. 
SzlavA. = Penavin Olga, Horvátországi (szlavóniai) magyar nyelvjárási atlasz. Magyar Nyelv, Irodalom és Hungarológiai Kutatások Intézete, Újvidék, 1984.

SzNySz. = Székely nyelvföldrajzi szótár. Összeáll. GÁlffy Mózes - MáRTON Gyula. Szerk. Kiss Jenö. Akadémiai Kiadó, Budapest, 1987.

ZsA. = RÓNAI BéLA, Zselici nyelvatlasz. Nyelvföldrajzi vizsgálatok a Zselicben. Magyar Történelmi Társulat Dél-dunántúli Csoportja, Pécs - Magyar Nyelvtudományi Társaság, [Budapest,] 1993.

\section{Hivatkozott irodalom}

BÁRCZI GÉza 1944. A magyar nyelvatlasz elökészitése. Magyar nyelvatlasz-bizottság, Budapest.

BÁRTH M. JÁNos 2016. A névföldrajz szerepe a nyelvjárástörténeti kutatásokban. In: Benö AtTILA T. Szabó Csilla szerk., Az ember és a nyelv - térben és időben. Emlékkönyv Szabó T. Attila születésének 110. évfordulóján. Erdélyi Múzeum-Egyesület, Kolozsvár. 134-143.

BÁRTH M. JÁnos 2018. Névföldrajzi térképlapok Erdélyböl. A helynévadás területi variabilitása a történeti adatok tükrében. Magyar Nyelvtudományi Társaság, Budapest. https://doi.org/ $10.26546 / 5061189$

Deme LÁszló 1955. A kérdőfüzetek anyagának összeállítása. In: BÁrCZI GÉzA szerk., A magyar nyelvatlasz munkamódszere. Akadémiai Kiadó, Budapest. 45-80.

FARKAS TAMÁs 2014. Dimenzionális szemlélet a névkutatásban. Általános kérdések és a családnévkutatás példája. Névtani Értesitő 36: 9-22.

FARKAs TAMÁs - Slíz, Mariann szerk. 2020. Tulajdonnevek és szótárak. ELTE Magyar Nyelvtudományi és Finnugor Intézet - Magyar Nyelvtudományi Társaság, Budapest. https://doi.org/ $10.26546 / 4892373$

N. FodOR JÁNOS 2014. A történeti személynévföldrajz mint a nyelvföldrajz egyik kutatási területe I. A nyelvföldrajzi módszer a névtani kutatásokban. Névtani Értesitő 36: 23-41.

N. FoDOR JÁNOS 2016. A történeti személynévföldrajz mint a nyelvföldrajz egyik kutatási területe II. Névföldrajzi módszer a nyelvjárástani kutatásokban. Névtani Értesítő 38: 19-31.

Hajdú Mihály 2003. Általános és magyar névtan. Személynevek. Osiris Kiadó, Budapest.

Hegedưs ANDREA 2008. Nyelvföldrajzi vizsgálatok a romániai magyar nyelvterületen az egyesített atlaszok felhasználásával. Doktori (PhD) értekezés. ELTE BTK, Budapest.

JuHÁsz Dezső 1999. A romániai magyar nyelvjárások atlasza névtudományi jelentőségéről. Névtani Értesitö 21: 395-400.

JuhÁsz Dezsö 2001. A nyelvföldrajz magyar eredményeiből. In: KIss JENő szerk., Magyar dialektológia. Osiris Kiadó, Budapest. 111-130.

Juhász Dezsö 2020. Tulajdonnevek a tájszótárakban. In: Farkas Tamás - Slíz Mariann szerk., Tulajdonnevek és szótárak. ELTE Magyar Nyelvtudományi és Finnugor Intézet - Magyar Nyelvtudományi Társaság, Budapest. 53-62. https://doi.org/10.26546/4892373.4

KÁzmér MikLós 1970. A falu a magyar helynevekben. XIII-XIX. század. Akadémiai Kiadó, Budapest.

MuRÁDIN LÁszLó 1966. A -ni, -nitt, -nul -nül határozórag-csoport funkciója és erdélyi elterjedtsége. Nyelv-és Irodalomtudományi Közlemények 10: 45-60.

Szabó Panna 2018a. A névföldrajzi kutatások magyar eredményeiből. Magyar Nyelv 114: 482-490. https://doi.org/10.18349/MagyarNyelv.2018.4.482

Szabó Panna 2018b. Nyelvföldrajzi vizsgálatok a magyar nyelvterület nyugati felén a dialektológiai atlaszok alapján. Doktori (PhD) értekezés. ELTE BTK, Budapest.

VÖRÖS FERENC 2006. Névkutatás és névföldrajz. Fórum Társadalomtudományi Szemle 8/1: 167-176. 
VöRös OтTó 1999. Vizrajzi köznevek szóföldrajzi és jelentéstani vizsgálata. A Magyar Nyelvtudományi Társaság Kiadványai 211. Magyar Nyelvtudományi Társaság, Budapest.

Szabó Panna

ORCID: https://orcid.org/0000-0002-9540-6374

ELTE Eötvös Loránd Tudományegyetem

Egyetemi Könyvtár és Levéltár

\section{Panna Szabó, Proper names in linguistic atlases}

The study offers an overview of the proper names included in Hungarian linguistic atlases. First, the lexicons of these atlases are examined, emphasising the reasons behind the low number of proper names. The linguistic atlases printed in Hungarian to date contain 6090 entries, but only 81 proper names. Anthroponyms can be found in 20 atlases, mostly in suffixed forms or nicknames. Other proper names include toponyms and the names of planets. Atlases from Romania are unique in this regard as the same headwords were collected most consistently. Existing linguistic atlases can be better utilised by onomastic research in geographic common nouns and words that have become anthroponyms (the names of professions, crafts, adjectives for internal or external characteristics) are also considered, as the number of these is much greater than that of proper names. 